\title{
A wake-up call
}

\section{How failing a PhD led to a strategy for a successful scientific career.}

\section{Bruce Alberts}

$\mathrm{O}$ ne of my most important formative experiences as a scientist was very traumatic at the time. In the spring of 1965, I had finished writing my PhD thesis at Harvard University, in Cambridge, Massachusetts, and had purchased aeroplane tickets to take my wife Betty and our oneyear-old daughter with me for a postdoctoral year in Geneva, Switzerland. Only one step remained - a meeting of my thesis committee to approve the granting of my $\mathrm{PhD}$ degree in biophysics. No one in recent memory had failed at this late stage. But to my great surprise, the committee failed me, specifying the need for more experiments that eventually required six more months of research.

This was, of course, a great embarrassment and a shock to my ego. There were the practical problems of having to remain at Harvard - our apartment had already been rented to the next tenant and my small family had nowhere to live. But most importantly, I was to spend the next few months struggling to answer two questions that would be critical for my future. What had gone wrong, and did I really have what it takes to be a scientist?

As an undergraduate working with Jacques Fresco in Paul Doty's laboratory at Harvard, I was handed a research project that proved to be very successful. My undergraduate thesis was quickly converted into two important papers in 1960. This largely undeserved success gave me a false image of how easy it would be to do science. It also enabled me to persuade Paul Doty to allow me to test my own theoretical model for the initiation of chromosome replication as the centrepiece of my $\mathrm{PhD}$ research.

According to my model, the sites at which DNA replication begins (now called replication origins) should be located at the two ends of each DNA helix in a chromosome. If this model was correct, the enzyme DNA polymerase should create a transient covalent linkage between the two complementary DNA strands at the tip of a chromosome (a 'DNA crosslink'). I began an extensive search in DNA genomes for crosslinks that were located near the sites where replication begins. None of the tests supported my particular model, but I did find other crosslinks in all of the chromosomes that I tested. I spent several years characterizing these mysterious and unexpected 'naturally occurring crosslinks', but even 40 years later, their structure and origin are still not understood (J.Mol.Biol.32, 405-421; 1968).

In retrospect, the shock of having my $\mathrm{PhD}$ thesis rejected in 1965 proved to be a

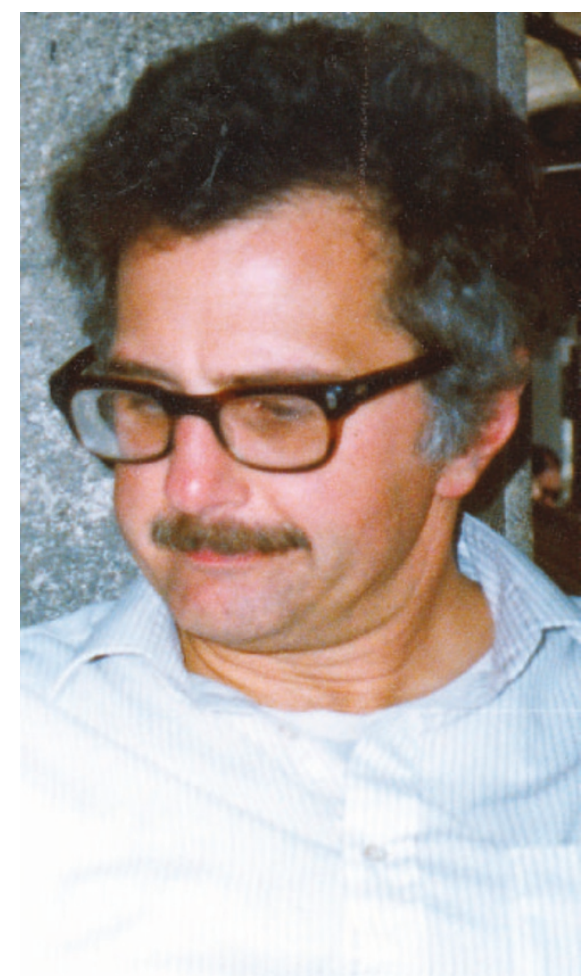

Bruce Alberts: 'failure' was a blessing in disguise.

critical step in shaping me as a scientist, because it forced me to recognize the central importance of the strategy that underlies any major scientific quest.

I had witnessed the frustration of scientists who were pursuing obvious experiments that were simultaneously being carried out in other laboratories. These scientists were constantly in a race. It had always seemed to me that, even if they were able to publish their results six months before a competing laboratory, they were unlikely to make truly unique contributions.

I had used a different strategy. My approach had been that of predicting how a particular biological process might work and then taking years to test whether my guess might be right. This was enormously risky. The good news was that I was carrying out experiments that were different from those being done by everyone else. The problem was that these tests could produce only a 'yes' or 'no' answer. If 'yes', I might be able to add something unique to the world's store of scientific knowledge. But if 'no', I would learn nothing of real value - in this case, I could eliminate just one of the many possible ways in which DNA replication might begin.

I wanted to continue to focus on how DNA is replicated for my postdoctoral work in Geneva. But what strategy should I choose? The months of analysis triggered by the wake-up call of my $\mathrm{PhD}$ failure finally produced an answer. I would look for a unique experimental approach, but one that would have a high probability of increasing our knowledge of the natural world, regardless of the experimental results obtained.

After a great deal of soul-searching, I decided that I would begin by developing a new method - one that would allow me to isolate proteins required for DNA replication that had thus far escaped detection. I knew that the enzyme RNA polymerase, which reads out the genetic information in DNA, binds weakly to any DNA sequence even though this protein's biologically relevant binding sites are specific DNA sequences. If the proteins that cause DNA to replicate have a similar weak affinity for any DNA molecule, I would be able to isolate them by passing crude cell extracts through a column matrix containing immobilized DNA molecules.

Arriving in Geneva in late 1965 with my $\mathrm{PhD}$ degree finally in hand, I found that by drying an aqueous solution of DNA onto plain cellulose powder, I could construct a durable and effective 'DNA cellulose' matrix. A large number of different proteins in a crude, DNA-depleted extract of the bacterium Escherichia coli bound to a column containing this matrix. Moreover, these DNA-binding proteins could be readily purified by elution with an aqueous salt solution.Using this new biochemical tool and a large library of mutant T4 bacteriophages obtained from Dick Epstein in Geneva, I discovered the T4 gene 32 protein after moving to Princeton a year later as an assistant professor. This proved to be the first example of a single-strand DNA-binding (SSB) protein, a structural protein that plays an important role in DNA processes in all organisms (see Nature 227, 1313-1318; 1970).

The strategy of investing in method development and then using this new method for a major series of experiments would be employed over and over again during the next 25 years of my career as a research scientist. As a result, my laboratory almost never felt that it was in a race with other laboratories, and our successes were sufficient to satisfy both me and many of the graduate students and postdoctoral fellows who would join my laboratory. It seems strange to recall that we may owe all it all to one very unhappy $\mathrm{PhD}$ thesis committee at Harvard, nearly 40 years ago.

Bruce Alberts is the president of the National Academy of Sciences, 500 5th Street, NW,

Washington DC 20001, USA. 